Dawson of Penn, afterwards presented the Baly Gold Medal to Dr. F. H. A. Marshall and the BissetHawkins Gold Medal to Sir George Newman, lately Chief Medical Officer of the Ministry of Health. The Baly Medal is awarded annually for distinction achieved in the science of physiology. The BissetHawkins Medal is awarded triennially for "such work in advancing sanitary science or in promoting public health as in the opinion of the College deserves special recognition".

\section{Care of Cripples and Invalids}

A JoINT conference of the Invalid Children's Aid Association and the Central Council for the Care of Cripples will be held on November 7-8 at the Drapers' Hall, Throgmorton Street, London, E.C. The opening address will be given by the Minister of Health, Sir Kingsley Wood. The subjects for discussion will be : (1) infectious diseases and their after-effects; immunisation and other preventive measures ; $(2)$ the problem of physical handicap in modern life ; (3) the after-effects of accidents; rehabilitation. Visits will also be paid to various homes and hospitals. The Conference fee, including the report of the proceedings, is 7s. 6d., and should be sent to Miss Wynne (Invalid Children's Aid Association) or Miss Nangle (Central Council for the Care of Cripples), Carnegie House, 117 Piccadilly, W.1, from whom further information may be obtained.

\section{Announcements}

Sir ALBERT HowARD, formerly director of the Institute of Plant Industry, Indore, will deliver a lecture entitled "The Manufacture of Humus by the Indore Process", before the Royal Society of Arts on November 13 at 8 p.m.

Prof. Hermann Levy will deliver the Sidney Ball lecture in the University of Oxford on October 29 at 5 p.m. He will take as his subject "The New Aspects of Industrial Combination" and the lecture will be given in the Examination Schools, Oxford.

The Masters Memorial Lectures of the Royal Horticultural Society will be delivered in the lecture room of the Society's new hall in Greycoat Street, Westminster, on November 5 and November 26, at 3.30 p.m., by Sir William Wright Smith, on "Problems connected with the Classification of Plants". Sir Arthur Hill and Sir Daniel Hall have consented to take the chair on these occasions.

Prof. Gregorio Maranón, president of the Spanish Academy of Medicine, has recently been elected president of the Hispano-Belgian scientific entente committee.

Dr. Fritz Lenz, professor of racial hygiene, University of Berlin, has been awarded the Josef Schneider medal by the medical faculty of the University of Würzburg.

A commitree has been formed for the erection of a monument at La Ciotat, by the sculptor Paul Gondard of Marseilles, to the brothers Louis and
Auguste Lumière, who were the first to exhibit cinematograph films in September 1895.

ON the occasion of the fiftieth anniversary of the first inoculation for rabies on July 20, a bust of Pasteur was unveiled at Havana in a square to which his name had been given, on the initiative of the academy of Sciences of Havana, in conjunction with the Franco-American Committee of Paris.

Prof. Wilhelm Haberling, of the Düsseldorf Academy of Medicine and joint editor of Mitteilungen zur Geschichte der Medizin, der Naturwissenschaften und der Technik, has recently been awarded the Sudhoff medal by the German Society of the History of Medicine for his eminent services to the study of the history of medicine.

VICTOR Cousin in 1848 described at length a MS. of the Abbey of Corbie now in the Municipal Library of Amiens, which contained a number of treatises by Roger Bacon, written while he was teaching in the University of Paris. Under the title "Opera Hactenus Inedita Rogeri Baconi", the Oxford University Press is publishing shortly the last-the thirteenth-of a series of fasciculi, completing the publication of these treatises, which represent the teaching of the Faculty of Arts in the first half of the thirteenth century. The editors are Mr. Robert Steele and the Rev. Père F. M. Delorme.

The Royal Commission for the Exhibition of 1851 has re-issued its list of whole-time awards for scientific research, other than professorships, offered by public and private bodies in Great Britain and Northern Ireland. The list does not include awards of value less than $£ 150$ a year, neither does it include awards offered by universities and scientific societies exclusively for the benefit of their own members. The list, which brings together in convenient form a good deal of useful information, can be obtained from the Secretary of the Commission, 1 Lowther Gardens, Fxhibition Road, London, S.W.7, price $6 d$.

Applications are invited for the following appointments, on or before the dates mentioned :

A senior assistant to the principal (also to teach mechanical engineering) in the Barrow-in-Furness Technical College-The Director of Education, Town Hall, Barrow-in-Furness (Nov. 4).

An assistant (III) at the Fuel Research Station, East Greenwich and a junior scientific officer at the Chemical Research Laboratory, Teddington-The Establishment Officer, Department of Scientific and Industrial Research, 16 Old Queen Street, S.W.1 (Nov. 5).

A senior lecturer in mathematics, and lecturers in mechanical and civil engineering in the Lester School and Institute, Shanghai-The Lester Trust, c/o Messrs. Viney, Price and Goodyear, Empire House, St. Martin's-le-Grand, London, E.C.1 (Nov. 30).

A lecturer in mechanical and civil engineering in the Rotherham College of Technology and Art-The Director of Education, Education Offices, Rotherham. 